\title{
Quando o alter ethos é homofóbico
}

\section{Lucas Nascimento}

Doutor em Língua e Cultura pela Universidade Federal da Bahia (UFBA), Brasil. mlucasnascimento@gmail.com

Resumo: Já que o ser humano se constitui intersubjetivamente, é interessante analisar, através da imagem que o sujeito projeta de si, a imagem que o outro faz dele. Esta imagem, chamo-a de alter ethos. Desse modo, ao repousar analiticamente sobre um pronunciamento em uma audiência pública da Comissão de Direitos Humanos, no Senado Federal do Brasil, em 2011, a respeito do Projeto de Lei anti-homofobia (PLC 122/2006), mostro a produtividade dessa noção à luz de uma análise dialógica da argumentação. Esta resulta de um evento epistemológico entre a Filosofia do ato responsável, fundamento do dialogismo de Bakhtin, e a Nova Retórica de Perelman e Olbrechts-Tyteca. Ora, essa perspectiva de análise privilegia não apenas o acordo, mas, sobretudo, a polêmica. Ao final, fica claro como o alter ethos ajuda a compreender o motivo da construção de um ethos, no caso específico, de um ethos anti-homofóbico.

Palavras-chave: Ethos. Alter ethos. Nova retórica. Homofobia.

\begin{abstract}
Since the human being is intersubjectively constituted, it is interesting to analyze, through the image that the subject projects from himself, the image that the other makes of him. This image, I call it alter ethos. Thus, analyzing a statement at a public hearing of the Human Rights Commission in the Brazil Federal Senate in 2011 about AntiHomophobia Bill (PLC 122/2006), I show the productivity of this notion to the light of a dialogical analysis of argumentation. This results from an epistemological event between the Philosophy of the responsible act, the basis of Bakhtin's dialogism, and the New Rhetoric of Perelman and Olbrechts-Tyteca. However, this analysis perspective privileges not only the agreement but, above all, the controversy. In the end, it is clear how the alter ethos helps to understand the reason for building an ethos, in the specific case, of an antihomophobic ethos.
\end{abstract}

Keywords: Ethos. Alter ethos. New rhetoric. Homophobia. 
Introdução

O eu humano se constrói a partir da imagem que vê projetada nos olhos do outro. A razão disso é que a consciência humana se constitui sob laços intersubjetivos, e não apenas de maneira subjetiva. Esse eu, no entanto, nem sempre concorda com a imagem que o outro faz dele, e muitas vezes reage verbal e energicamente a isso. Quando uma pessoa vê que a outra a considera homofóbica, por exemplo, ela busca construir uma imagem de si para mostrar que não o é. Ora, por meio dessa imagem construída, o que desde Aristóteles a retórica chama de ethos, é possível ver como o sujeito se enxerga através dos olhos do outro, e como ele se contrói discursivamente a partir disso.

Reações como essas são possíveis porque o ser humano se constitui intersubjetivamente. A literatura dostoivskiana é formidável para se observar isso. Em uma breve análise que o filósofo russo Mikhail Bakhtin faz do romance Gente Pobre de Dostoiévski, ele observa que "a autoconsciência do homem pobre revela-se no fundo da consciência socialmente alheia do outro sobre ele" (2013, p. 238). Aquele homem pobre olha-se através do olhar do outro, contudo, ele entra em polêmica com a imagem que o outro faz dele, já que discorda da conclusão alheia a seu respeito.

Uma pessoa reagir ao simulacro que uma outra faz de seu discurso é próprio da modalidade polêmica, cuja presença tem sido cada vez mais notada entre nós nas últimas décadas (AMOSSY, 2014). Sendo assim, uma perspectiva profundamente intersubjetiva (e dialógica, claro) ilumina nosso olhar para ver de maneira singular como isso acontece. Para explorar então a singularidade desse olhar, argumento que é possível acessar, a partir dos olhos do próprio sujeito, a imagem que o outro faz dele, o eu para o outro.

Em uma audiência pública em torno do Projeto de Lei anti-homofobia (o PLC 122/2006) ${ }^{1}$, na Comissão de Direitos Humanos e Legislação Participativa do Senado Federal do Brasil, o senador Magno Malta não concorda com a imagem de "homofóbico" que os defensores do projeto fazem dele, dos cristãos tradicionais e dos políticos antiplc122. Como ele responde a isso? Ele tenta associar a si atos que mostrem que não é homofóbico, na intenção de reconstruir a percepção alheia de seu ethos, ao mesmo tempo em que aponta a intolerância do PLC com o divergente. O que há aí? Uma imagem-resposta à

\footnotetext{
${ }^{1}$ Por vezes, além desses epítetos, serão usadas as seguintes designações para referir-se ao PLC 122/06: PLC 122, PL122, “Projeto Anti-homofobia”, "PL da Homofobia”.
} 
imagem que o outro faz do eu, o alter ethos. A escolha dessa palavra em latim se dá porque já é conhecida no âmbito das ciências humanas, especialmente na psicologia, associada ao alter ego, ou mesmo forma a palavra "alteridade", satisfazendo o sentido de "outro" em relação tensiva com o eu. Ou seja, o alter ethos é justamente a imagem que o sujeito argumentante faz da imagem que o outro faz dele. Ora, esse outro ethos pode ser analisado através dos próprios atos argumentativos do sujeito, e é justo isso que farei mais à frente.

Dito isso, neste artigo, mostro a pertinência dessa noção a partir das lentes de uma análise dialógica da argumentação. Para tanto, partindo de uma perspectiva dialógica (BAKHTIN, 2010; 2011; 2013), estabeleço um diálogo muito pontual com as noções em torno de ethos (MAINGUENEAU, 2006, 2008; AMOSSY, 2008; CHARAUDEAU, 2013; MEYER, 2007; PERELMAN e OLBRECHTSTYTECA, 2005) para chegar à noção de alter ethos. E, ao final, detenho-me em uma análise do pronunciamento supracitado do senador Magno Malta.

\section{A imagem externa na análise dialógica da argumentação}

Essa noção de alter ethos desenvolvi em minha tese de doutorado, no âmbito da proposta de uma análise dialógica da argumentação (NASCIMENTO, 2018). Esta resulta de um evento epistemológico entre a Filosofia do ato responsável, fundamento do dialogismo de Bakhtin (2010, 2011, 2013), e a Nova Retórica de Perelman e Olbrechts-Tyteca (2005). Essa perspectiva de análise privilegia não apenas o acordo, mas, sobretudo, o desacordo profundo, digo, a polêmica, e, ao mergulhar no motivo do ato, investiga como os sentidos emergem à consciência dos sujeitos argumentantes.

Ora, a atualização de sentido emerge por meio da apreciação valorativa do sujeito, perspectiva que leva bastante a sério o ativismo do self no mundo axiológico. Mas, como é possível compreender isso enquanto um jogo de imagens, se Chaim Perelman ao insistir na dimensão comunicacional da relação entre orador e auditório, embora nos dê pistas, como assegura Ruth Amossy (2010), não detalha como a imagem feita do auditório pelo orador se traduz concretamente na fala? Tendo isso em vista, defendo que um olhar capaz de enquadrar a relação entre orador e auditório como profundamente intersubjetiva nos ajuda a compreender melhor o que acontece.

Esse olhar se efetiva no encontro entre Bakhtin e Perelman, em que lanço mão da noção de empatia ativa, no russo, a vzhivanie (BAKHTIN, 2010). Esta torna-se possível porque se dá em dois momentos, os quais não são 
necessariamente uma sucessão temporal, mas uma interpenetração, quais sejam: o primeiro é a saída de si para empatizar-se com o outro, o momento da compenetração e identificação; e o segundo momento é o da objetivação, do voltar a si, da exotopia, pondo em cena um excedente de visão.

Ante uma questão problemática, o sujeito-orador entra no mundo do sujeito-auditório para de lá olhar, a fim de ter uma visão privilegiada de seus valores e do problema em pauta. O sujeito-orador, ao fazer isso, volta-se para seu mundo, uma vez que ele não se dissolve dentro do outro e não perde seu lugar de fora, a sua exotopia, que é condição do acabamento do mundo axiológico do outro. Isso se dá pelo fato de o sujeito-auditório ser uma construção do sujeito-orador, o que implica que este dá-lhe um acabamento, enquadrando-o dentro de um ambiente, de certas categorias e valores. Nesse movimento, a resposta do sujeito argumentante à questão do outro pode constituir-se um ato argumentativo concreto.

Isso é deveras interessante porque esse acabamento não é estanque durante o processo persuasivo. Ele vai se modificando à medida que a visão do sujeito argumentante vai se modificando em relação ao outro, revelando-se mesmo um processo profundamente dialógico, em que o eu vai se moldando frente ao outro e o outro frente ao eu, em uma construção intersubjetiva de si e da argumentação. Aqui há a relação do ethos, da imagem externa do sujeito, que só é possível enxergar-se a si mesmo por meio dos olhos do outro². Além disso, temos aí o eu para-si, condição de formação de sua identidade subjetiva, quanto um eu para-o-outro, condição necessária para inserção de sua identidade no plano relacional, e o "outro para mim" dialógicos (BAKHTIN, 2010; 2011).

A imagem que o sujeito argumentante constrói de si é para o outro, como também é a partir do outro. Nesse sentido, há aí os valores que moldam o sujeito e que o impulsionam a agir. Além disso, podemos falar não apenas da relação entre o sujeito-orador e o sujeito-auditório, mas também de um terceiro. Este pode ser aproximado, de certa forma, aos valores ideais, a um possível auditório universal em que o que seria comum a um, poderia ser,

\footnotetext{
${ }^{2}$ Como dito na introdução, ao analisar o romance Gente Pobre, Bakhtin (2013) observa que o homem pobre se olha através do olhar do outro. Por conta disso, na análise do romance, Bakhtin resume: "Na autoconsciência do herói penetrou a consciência que o outro tem dele, na autoenunciação do herói está lançada a palavra do outro sobre ele; a consciência do outro e a palavra do outro suscitam fenômenos específicos, que determinam a evolução temática da consciência de si mesmo, as cisões, evasivas, protestos do herói, por um lado, e o discurso do herói com intermitências acentuais, fraturas sintáticas, repetições, ressalvas e prolixidade, por outro"“ (BAKHTIN, 2013, p. 240).
} 


\section{$\mathrm{EI} D \mathrm{dA}$}

Revista Eletrônica de Estudos Integrados em Discurso e Argumentação, Ilhéus, n. 18, abr.2019.

supostamente, comum a todos (PERELMAN e OLBRECHTS-TYTECA, 2005). Assim, é possível enxergar mais nitidamente, a partir da maneira com a qual os sujeitos enquadram uns aos outros, o jogo de imagens que constitui a relação entre orador e auditório.

A partir disso tudo, surgiu então a questão: é possível analisar, dialogicamente, por meio do discurso do sujeito argumentante, quem é ele para seu outro e como ele se constrói a partir disso? Ou seja, pode-se acessar, por meio do ato polêmico, a partir do olhar do próprio sujeito, a imagem que o outro faz dele, o eu para o outro? Eis a proposta do alter ethos.

\section{A pessoa, seus atos e o ethos}

Para os antigos gregos, em torno da palavra ethos giram os sentidos de imagem de si, a personalidade, os traços do comportamento, o caráter, a escolha de vida e de sua finalidade (de onde advém a palavra ética). Claro, esses termos não parecem em absoluto interligados, no entanto, todos estão vinculados de alguma maneira ao papel do orador. Por isso, é formidável a definição englobante que Michel Meyer nos oferece de ethos: "o éthos é uma excelência que não tem objeto próprio, mas se liga à pessoa, à imagem que o orador passa de si mesmo, e que o torna exemplar aos olhos do auditório, que então se dispõe a ouvi-lo e a segui-lo" (2007, p. 34).

No Tratado da argumentação, seus autores versam, de maneira específica, sobre as múltiplas relações entre a pessoa e seus atos. Eles as colocam na categoria das 'Ligações de Coexistência', já que dizem respeito ao fato de duas realidades de nível desigual se unirem. Assim, nessa grande obra, Perelman e Olbrechts-Tyteca (2005) trabalham com a categoria de pessoa, cuja construção está ligada ao que se considera próprio do ser de quem fala natural, não transitório -, referindo-se a um elemento de estabilidade, e que se vincula, de certa forma, a seus atos.

Por ato, vale lembrar, Perelman e Olbrechts-Tyteca (2005, p. 339) definem como "tudo quanto pode ser considerado emanação da pessoa, sejam eles ações, modos de expressão, reações emotivas, cacoetes involuntários ou juízos". Concepção que pode muito bem ser englobada pela noção de ato ético em Bakhtin (2010), uma vez que a perspectiva do filósofo 
russo é mais ampla e detalhada, envolvendo os elementos que perpassam, inclusive, pelo ato de pensar sem necessariamente uma expressão externa ${ }^{3}$.

Diz-se que a prática recorrente de um determinado ato pode acarretar na (re)construção da pessoa, ou de sua imagem, fornecendo subsídios para classificá-la em categorias passíveis de certas qualificações. Isso se torna possível porque "a estabilidade da pessoa jamais está completamente assegurada", e ainda, como afirmam Perelman e Olbrechts-Tyteca, são técnicas linguísticas que contribuem "para acentuar a impressão de permanência, sendo a mais importante o uso do nome próprio" (2005, p. 335). Não é à toa que é possível ver que pessoas são chamadas de preguiçosas, fofoqueiras, gulosas, porque pode haver designação da pessoa por alguns de seus traços; por certos sentimentos (o orgulhoso da família); por seus posicionamentos filosófico (o niilista), religioso (o cristão, o muçulmano), político e ideológico (o progressista, o conservador) etc. Fato é, a dinâmica da relação entre o ato e a pessoa é viva mesmo quando ela está morta, já que a construção da pessoa jamais está terminada, e os atos que podem ser atribuídos a ela vão dando nova coloração à imagem que se tinha cristalizada.

Nessa compreensão dialógica da construção que a pessoa faz de si, é possível compreendermos melhor como se dá a construção do ethos. Como isso pode ser feito? Visualizando o motivo da seleção de atos atribuídos a si e ao outro, a qual determina a construção de certo ethos em resposta a um alter ethos, digo, a uma imagem que o outro faz do sujeito.

De tudo isso, interessa-me aqui focar no quesito em que o discurso é tomado como ato do sujeito argumentante. Primeiro, porque o discurso é a manifestação por excelência da pessoa; segundo, porque, como nos dizem Perelman e Olbrechts-Tyteca (2005, p. 361), ele "desempenha um papel muito importante na argumentação"; e, terceiro, porque a interação entre orador e discurso é que caracteriza a argumentação em oposição à demonstração.

A impressão que o orador dá de si é muito importante na apreciação de sua argumentação por seu auditório. Sabendo disso, Aristóteles, há mais de dois milênios, no segundo livro da Retórica, propôs formalmente a noção de ethos. Esta diz respeito à impressão favorável que o orador dá de si com vistas a atrair a prônesis (a prudência), a aretè (a virtude) e a eunoia (a benevolência).

\footnotetext{
${ }^{3}$ Muito embora, em Perelman e Olbrechts-Tyteca (2005), ato também refira-se à relação do orador com seu auditório íntimo. De todo modo, nada impede que a noção de ato responsável abarque as concepções de ato aqui explicitadas da Nova Retórica e lhes amplie as fronteiras filosóficodiscursivas, de maneira que se possa falar de ato polêmico e de sujeito argumentante, como já mostrei em minha tese (NASCIMENTO, 2018).
} 
Essa impressão, o estagirita a considerava como uma prova construída pelo discurso. Como diz Maingueneau (2008, p. 13), ao tratar do ethos retórico, "esse ethos está ligado à própria enunciação, e não a um saber extradiscursivo sobre o locutor".

Sem dúvidas, o ethos está ligado ao ato de enunciação, seguindo-se certa tradição de interpretação aristotélica. No entanto, essa interpretação da noção não é um ponto pacífico na leitura feita de Aristóteles. Isso porque o ethos, nas diferentes obras do estagirita (Ética a Nicômaco, Política e Retórica), recebe diferentes tratamentos. Sobre a questão, Paveau (2015, p. 120) assegura: "no texto de Aristóteles, o caráter moral ou não do ethos permanece ambíguo" 4 . De todo modo, não se deve ignorar, como defendem Maingueneau (2008, p. 15), Charaudeau (2013) e Amossy (2008), em sintonia com toda tradição de Isócrates, Cícero e dos retóricos da Idade Clássica, que o auditório constrói representações do orador antes mesmo que ele fale.

Uma visada sobre os estudos contemporâneos do ethos aponta-nos para a problemática de sua eficácia residir no fato de ele se imiscuir na enunciação sem ser explicitamente enunciado (MAINGUENEAU, 2008). Na perspectiva de Ducrot (1987), o ethos não é dito no enunciado, contudo se mostra no ato de enunciação ${ }^{5}$. Ou seja, o ethos não diz respeito ao que se diz sobre si mesmo no conteúdo do discurso, mas está ligado à aparência construída pela cadência, pela entonação, pelas palavras e pelos argumentos escolhidos.

O que todas essas perspectivas nos mostram é que a construção da imagem do sujeito argumentante se dá tanto pelos dados prévios ao discurso, quanto pelos acionados pelo próprio ato enunciativo. Além disso, o próprio sujeito ajusta a sua imagem à imagem que o outro faz dele previamente à argumentação. Em outras palavras, o ethos funda-se num cruzamento de olhares, como aponta Charaudeau: "olhar do outro sobre aquele que fala, olhar daquele que fala sobre a maneira como ele pensa que o outro o vê" (2013, p. 115).

Tendo esse feixe de olhares em conta, chamo atenção para o fato de o sujeito falar das qualidades de seus feitos em seu próprio discurso. Como mostrarei mais abaixo, o Senador Magno Malta fala de seus feitos na

\footnotetext{
${ }^{4}$ E Eggs diz mais: "Em Retórica de Aristóteles, estamos diante de dois campos semânticos opostos ligados ao termo ethos: um no sentido moral e baseado em epieikeia, abrange atitudes e virtudes como honestidade, decoro ou equidade; o outro, no sentido neutro ou objetivo de hexis, reúne termos como hábitos, usos e costumes ou caráter" (EGGS, 1999, p. 32 apud PAVEAU, 2015, p. 120).

${ }^{5}$ A partir das concepções de Ducrot (1987), tem-se o locutor-L, que é o locutor apreendido como enunciador, e o locutor-lambda, que é o locutor apreendido como ser no mundo.
} 
recuperação de viciados em drogas e do apoio a um candidato transexual. Há quem veja nisso apenas um autoelogio, cujo resultado pode ser negativo. De modo geral, as vertentes interpretativas ligadas ao ethos fazem ressalvas ao fato de o orador falar de si ao tomar a palavra. Argumentam que, embora o discurso contribua para se construir uma boa imagem do sujeito argumentante, o autoelogio não é aconselhável para conseguir essa boa impressão, na maioria dos casos, ele "produz um efeito deplorável sobre os ouvintes", asseguram Perelman e Olbrechts-Tyteca (2005, p. 364). Não é à toa que tal procedimento Platão associava aos sofistas, uma vez que, ao estar preocupado mais com a verdade do que com a adesão, ele não enxergava valor no prestígio para buscá-la, chamando tais sofistas de gabolas.

Como estamos lidando, no entanto, com a questão da adesão, no ato argumentativo de um sujeito, sobretudo de um político, o autoelogio pode ser motivado pela tentativa de construir certa imagem ${ }^{6}$, ou de reafirmá-la, e ainda, pode ser a tentativa de o orador se reconstruir diante do outro, uma correção da imagem de si. E, para isso, ele aciona os feitos que lhe convêm. Ora, justo a partir desses atos prévios atribuídos a si, acredito ser possível observar mais claramente como o sujeito argumentante vê a si mesmo através dos olhos do outro, seu alter ethos, ou seja, o outro do ethos.

\section{O alter ethos como ato polêmico}

Sabemos que os atos de um sujeito não são bem compreendidos isoladamente. Na perspectiva de uma análise dialógica da argumentação polêmica, há uma arquitetônica que compreende o evento polêmico, o ato polêmico e o microato polêmico ${ }^{7}$. Cada um pode ser analisado separadamente, mas fazem parte de um todo. O que isso tem a ver com o alter ethos? Apenas para lembrar, o alter ethos é a imagem que o sujeito argumentante faz da imagem que o outro faz dele.

\footnotetext{
${ }^{6}$ Esta pode ir desde uma imagem diferente a uma contrária e ofensiva ao que sujeito faz de si mesmo. Contudo, é importante deixar muito claro que essa alter imagem nem sempre precisa ser exatamente contrária ao desejo do orador, ela pode manifestar-se apenas como imagem diferente que motiva uma imagem-resposta do sujeito argumentante. Como nos casos em que analiso o alter ethos são imagens contrárias (NASCIMENTO, 2018), uma vez que o contexto é de um evento polêmico, a aplicação dessa noção ainda precisa ser testada em análises cujas interações não sejam necessariamente polêmicas.

${ }^{7}$ Retomarei os outros dois, por isso logo explico aqui o que é o microato polêmico. Ele pode ser uma palavra, uma expressão valorada ou energizada por uma polêmica. Ele é, por assim dizer, um produto posto em ato, cujo sentido concreto se atualiza dependendo da posição do sujeito argumentante nos campos discursivos em disputa no seio do evento polêmico.
} 
O recorte que faço da análise sobre o alter ethos homofóbico faz parte de um estudo maior que envolve o evento polêmico religiosoafetivo em torno da criminalização da homofobia. O que seria isso? No Senado Federal do Brasil, em 2007, dois posicionamentos antagônicos se formam, isto é, em lados opostos, dois grupos (o proponente e o oponente) emergem enquanto adversários posicionados em campos discursivos contrários, em torno do famoso Projeto de Lei da Câmara, n 122/06 (PLC 122/06). Nesse cenário de polarização, os sujeitos envolvidos acionam e atualizam uma memória e um arsenal argumentativo ${ }^{8}$ (ANGENOT, 2008) polêmico para defenderem seus pontos de vista respeitantes à criminalização do preconceito e da discriminação à comunidade LGBT no Brasil.

Nesse intercurso, o grupo dos proponentes do PLC 122, que designo de afetivossexuais reformistas (do campo afetivossexual reformista) ${ }^{9}$, argumentam que o país é homofóbico e que a pregação dos religiosos cristãos de que a prática homossexual é pecado figura como preconceituosa, porquanto está na causa profunda da "homofobia", cujo imperativo para se passar a remediar tal opressão e violência seria a aprovação da lei antihomofobia. Do outro lado, o grupo dos oponentes, que chamo de religiosos tradicionalistas (do campo religioso tradicionalista), asseguram que também são contra a "homofobia" e que, por assim dizer, não são homofóbicos. Contudo, eles opõem-se veementemente às versões do PL122 porque este teria um espírito totalitário, sendo causa de emergente preconceito aos cristãos por terem uma opinião divergente da comunidade LGBT a respeito da prática homossexual.

Nessa disputa, cada um dos lados mostra os valores amados e os valores odiados através de diferentes posicionamentos polêmicos. Pois bem, acabo de apresentar uma visão abrangente, fruto da aplicação da noção de evento polêmico. Ora, o evento polêmico é o encontro de posicionamentos polêmicos, fundantes de dois campos discursivos antagônicos, responsáveis por atualizar entidades de outras polêmicas, ao disputarem os sentidos de um mesmo objeto do discurso em um dado cronotopo. No caso específico, no

\footnotetext{
8 Angenot (2008), ao analisar as polêmicas e as lógicas da modernidade, falará de arsenal argumentativo como conjunto de argumentos mobilizados, os quais aparecem como se fossem munições para a batalha argumentativa.

${ }^{9}$ Designo como campo afetivossexual, porque ele figura como uma região do campo afetivo, cujas pautas dizem respeito às questões da ordem da sexualidade e do afeto. No entanto, não estou chamando de homoafetivo, o que até seria uma possibilidade, porém não tão abragente, uma vez que o termo afetivossexual abarca questões amplas de identidade de gênero, bissexualidade, transexualidade etc., que vão além da homoafetividade, em cujos assuntos o PLC 122 toca.
} 
espaço público político sob a análise dos enunciados concretos produzidos dentro do gênero audiência pública.

Nessa dinâmica dialógica, os sujeitos em disputa mobilizam argumentos com vistas a responder às vozes que aparecem, seja para persuadir ou dissuadir, a respeito do PLC 122. Esses argumentos, chamo-os de atos polêmicos. Por ato polêmico pode-se compreender os acordos, os argumentos e os posicionamentos mobilizados no processo argumentativo, imantados pelo evento polêmico. Nisso está a mobilização do ethos, cuja análise do alter ethos torna-se possível nessa vontade de compreensão.

O evento polêmico torna-se efetivo porque cada sujeito argumenta a partir de campos opostos. Dessa maneira, a polêmica se instaura na própria construção da imagem que os sujeitos fazem de si; ali é possível, por assim dizer, ver uma relação de amor e ódio no espelhar das imagens. Por conta disso, o alter ethos, percebido pelo sujeito argumentante, pode ser um bloqueio para a adesão à tese que seu interlocutor tenha proposto, dado que o sujeito pode se indispor completamente contra ele. Indisposição esta motivada por um bloqueio emocional resultante do jogo polêmico de imagens.

No caso em análise, como se está no espaço político, o ethos político é efeito de uma complexa alquimia feita de traços pessoais de caráter, de corporalidade, de declarações verbais, de comportamentos, tudo isso avaliado pelos cidadãos que atribuem valores negativos ou positivos a esses atos associados ao sujeito político. Como assegura Charaudeau: "Toda construção do ethos se faz em relação triangular entre si, o outro e um terceiro ausente, portador de uma imagem ideal de referência" (2013, p. 137). Por conta disso que, "no discurso político, as figuras do ethos são ao mesmo tempo voltadas para si mesmo, para o cidadão e para os valores de referência" (CHARAUDEAU, 2013, p. 137). Todavia, é importante considerar que, por vezes, sobretudo num caso de uma discussão pública, o político não tem apenas o cidadão como auditório, mas também um outro político ou um interlocutor com quem trava uma discussão. Vejamos o pronunciamento (o ethos e o alter ethos) do senador Magno Malta abaixo. 


\section{$\mathrm{EI} \square \mathrm{dA}$}

\section{O Ethos anti-homofóbico contra o alter ethos homofóbico}

O Senador Magno Malta ${ }^{10}$, opositor ao PLC 122 e integrante da Bancada Evangélica, defende-se de que não é homofóbico, ao mesmo tempo em que nos deixa enxergar como ele vê a maneira como seus opositores o veem, digo, o seu alter ethos. Mas como ele faz isso? Através da construção de um ethos anti-homofóbico.

O primeiro passo dado pelo Senador Malta é construir um ethos democrático. Logo após tomar a palavra e fazer as saudações iniciais, como segundo orador a falar ${ }^{11}$ na Audiência Pública do Senado Federal, em 2011, o parlamentar busca construir uma imagem de político democrático, em cujo traço principal focado é a tolerância. Ele diz: [1] "cada qual defende o que acredita, e nós precisamos respeitar isso" (BRASIL. CDH, 2011, p. 7). Para reforçar essa imagem visada, o senador Malta mostra-se uma pessoa aberta ao diálogo com seus adversários.

O senador Malta defende que o PLC 122, que corria no Senado desde final de 2006, "apodreceu" e que, portanto, deve-se discutir ali um projeto sobre a intolerância contra qualquer pessoa, e não apenas contra um grupo específico, o dos homossexuais. Ele assegura: [2] "Penso que o que o Brasil espera que nós versemos é sobre um texto que fale de intolerância". Assim, anuncia uma de suas teses centrais, a de que [3] "Ninguém tem direito de ser intolerante com ninguém” (BRASIL. CDH, 2011, p. 7). Para reforçá-la, ele toma exemplos de situações cotidianas a fim de mostrar que não se deve ser intolerante com estrábico, deficiente, nordestino, homossexual ou com religioso.

Magno Malta argumenta que o espírito do PLC 122, e de seus proponentes, é intolerante. Assim, ao apontar atitudes intolerantes dos defensores do PL, o senador tenta reforçar seu ethos de tolerância democrática através de certo constraste. Dessa maneira, ele vai construindo uma argumentação para mostrar que os cristãos e os contrários ao PLC 122 passaram a ser vítimas de intolerância praticada por defensores do projeto. Para sustentar seu ponto de vista, Malta mostra que o movimento LGBT teria praticado intolerância com os símbolos da fé cristã/católica. Em um dos

\footnotetext{
${ }^{10}$ É pastor evangélico, cantor e foi Senador da República, de 2003 a 2018, pelo Partido da República do Estado do Espírito Santo. Na ocasião era membro da Frente Parlamentar Evangélica e conhecido por Presidir a Comissão da Pedofilia.

${ }^{11}$ No gênero audiência pública, a reunião é dirigida pelo presidente da Comissão, na ocasião o Senador Paulo Paim, que media a discussão, facultando a cada orador a sua fala. Nessa reunião, quem primeiro falou foi a relatora do PLC 122, Senadora Marta Suplicy.
} 
episódios citados, participantes da Parada do Orgulho LGBT $^{12}$ teriam levado para a Avenida Paulista santos católicos, insinuando com eles posição sexual.

$\mathrm{Na}$ perspectiva do senador Magno Malta, o Projeto de Lei antihomofobia é intolerante porque os defensores buscam criminalizar quem não concorda com o posicionamento LGBT. Além disso, o senador não concorda que o crime de homofobia seja análogo ao de racismo, como intenciona o projeto, uma vez que, embora se deva respeitar a "opção" e o requerimento de direitos pelos indivíduos, Malta argumenta que [4a] "não se pode comparar raça com quem fez opção por ser homossexual” (BRASIL. CDH, 2011, p. 9). Mas, a partir disso, ele revela o que realmente acha do PL122: [4b] "Ora, na verdade, este projeto não é um requerimento de direitos; é criminalização de quem não concorda" (BRASIL. CDH, 2011, p. 9).

Nesse caso, o PL seria intolerante não apenas com os religiosos, mas também com os políticos contrários ao projeto. Então, enquanto político, o senador Magno Malta se coloca no lugar de vítima de mais uma intolerância. Para argumentar sobre isso, ele faz menção ao artigo “Omissão inaceitável”, publicado na Folha de São Paulo"13, no dia 19 de novembro de 2011, pela Senadora Marta Suplicy, em que ela insinuaria que "o aumento de crimes homofóbicos no Brasil” se dá por consequência das atitudes dos senadores que se opõem ao PLC 122, fazendo plataforma política em nome da questão religiosa.

Todavia, na ótica do senador Malta, a senadora Marta estaria desrespeitando os opositores ao projeto ao fazer tal acusação e ao insinuar que eles são responsáveis pela continuação dos crimes de homofobia no país. Para reforçar seu ponto de vista, e seu ethos de político democrático, Malta defende a senadora Marta, para imediatamente fazer uma analogia: ele argumenta que, assim como Marta não fora responsável pelas crianças que morreram no seu mandato de prefeita em São Paulo, nem muito menos responsável pelos homossexuais e pelos mendigos agredidos durante a sua gestão; de igual maneira, os senadores, que são contra a versão do PLC 122, também não são responsáveis pelos crimes contra os homossexuais, uma vez

\footnotetext{
${ }^{12}$ Muito provavelmente ele se refira à $15^{\text {a }}$ Parada do Orgulho LGBT que aconteceu em junho de 2011 em São Paulo.

${ }^{13}$ O Senador refere-se a um artigo no Estado de São Paulo, contudo foi na Folha de São Paulo. SUPLICY, Marta. “Omissão inaceitável”. Folha de São Paulo. São Paulo, 2011. Disponível em: http://www1.folha.uol.com.br/fsp/opiniao/9733-omissao-inaceitavel.shtml. Consultado em 10 set.2016.
} 
que o que eles desejam é chegar a um texto que não tenha intolerância, por isso ainda não aprovaram o PLC.

Se até aqui o Senador Magno Malta constrói um ethos de tolerância democrática, sempre no contraste com seu outro, os intolerantes proponentes do PLC 122, agora, ele reforça sua imagem de tolerante, dando lugar a um ethos de solidariedade [5], algo muito próprio ao político brasileiro:

[5a] Sobre a questão dos homossexuais no Brasil, digo para a senhora [Senadora Marta Suplicy] de cadeira, faz 30 anos que recupero drogados, Senadora [5b]. Pela minha instituição de recuperação de drogados passaram $n$ homossexuais, e lá tem hoje se recuperando... [5c] O meu Partido está cheio de homossexuais [5d]. No meu Estado... Moa é um expoente, porque é presidente de Câmara, é um político que ganhou proeminência por sua própria capacidade, aliás, que fez a campanha eleitoral com uma foto comigo [5e].

Observe que o argumentante aciona imagem de um político solidário com todos. O ethos de solidariedade, como nos lembra Patrick Charaudeau, "faz do político um ser que não somente está atento às necessidades do outro, mas que as partilha e se torna responsável por elas" (2013, p. 163). Observe que o Senador Malta faz isso trazendo à luz seus atos prédiscursivos ${ }^{14}$, lançando mão de exemplos pessoais, com vistas a mostrar suas ações comprometidas com causas sociais, especificamente, de recuperação de viciados em drogas [5b]. Vale lembrar que, anteriormente, ele já havia citado que trabalha contra o abuso de crianças. O objetivo argumentativo dessa espécie de autoelogio é mostrar-se alguém não apenas tolerante aos homossexuais, mas também solidário, uma vez que inclui em seu trabalho social a recuperação de viciados homossexuais [5c].

A maneira de o senador Malta dizer que não é homofóbico é trazendo à tona sua aliança política com um candidato transexual de seu partido [5e]. Ele se refere a Moacyr Sélia Filho ${ }^{15}$ (Moa), transexual e então vereador do município de Nova Venécia, no Espírito Santo. Porém, aqui, cabe uma observação, porque se esse ethos de solidariedade está ligado ao desejo de estar junto, de não se distinguir dos outros membros do grupo e de ir "ao

\footnotetext{
${ }^{14}$ Por pré-discursivos aqui, refiro-me ao que antecede ou vem antes ao discurso feito no momento da enunciação. Nisso, faço referência à noção do ethos pré-discursivo de Maingueneau (2006).

${ }^{15}$ Moa foi a primeiro transexual a ser dirigente de uma Câmara de vereadores no Brasil, entre 2006 e 2008, e foi vice-presidente do Partido Republicano. Moa faleceu em 2017. Em 2011, Moa saiu em defesa do Senador Magno Malta a respeito de seu posicionamento quanto ao PLC 122. Quanto à polêmica sobre a homofobia, ele assegurou: "Já passamos da fase da violência física contra os homossexuais, existem casos isolados, mas a comunidade, mesmo com intolerância e discriminação, tem tratado o movimento LGBT dentro do debate político democrático". Disponível em: http://portugues.christianpost.com/news/homofobia-vereador-transexual-sai-mais-uma-vezem-defesa-de-magno-malta-2612/. Consultado em janeiro de 2018.
} 
encontro das ideias e pontos de vista dos outros grupos" (CHARAUDEAU, 2013, p. 163), os exemplos do Senador deixam ver, no caso do trabalho com o centro de recuperação, que ele é solidário ao sujeito viciado. Logo, a solidariedade é a essa pessoa do viciado, e não às questões demandadas pela política identitária homossexual.

Como todo ato argumentativo é resposta a outro ato, o sujeito argumentante, ao trazer para o discurso seus atos pré-discursivos para se defender de um estereótipo que estava sendo construído, permite que o analista tenha acesso ao seu alter ethos. Observa-se, portanto, o ethos do sujeito argumentante em relação polêmica com seu outro, o alter ethos, o que mostra que enquanto o outro dá um acabamento na imagem externa do sujeito, este, entretanto, não tem de si uma imagem esgotada. Desse modo, a polêmica na dimensão etóica pode ser velada, mas logo estoura numa polêmica aberta. Assim, a imagem que o argumentante tem da imagem que o outro tem dele determina a imagem que o sujeito argumentante constrói de si como resposta ao outro. Ou seja, o ethos de anti-homofobia ${ }^{16}$ é uma réplica ao alter ethos de homofobia (Gráfico 1).

Ora, o sujeito argumentante vê-se rotulado como homofóbico por seus adversários. Isso abrange o âmbito religioso, pessoal e político, uma vez que ele responde e fala em nome de todos esses grupos. Por conta disso, a tentativa de construir um ethos de tolerância democrática ${ }^{17}$ e um ethos solidário serve de estratégia argumentativa para refutar seu alter ethos homofóbico. Para o senador Magno Malta, ele não é homofóbico, porque se propõe a combater toda e qualquer forma de intolerância e é tolerante e solidário com os homossexuais. Ele argumenta que nem ele, nem os cristãos, nem a nação são homofóbicos, tanto que, próximo ao final de seu pronunciamento, Malta declara energicamente: [7] “... a nação não é homofóbica" (BRASIL. CDH, 2011, p. 45).

\footnotetext{
${ }^{16}$ Poderíamos até utilizar o termo não-homofóbico, em vez de anti-homofóbico. Porém, como o senador entende que combater a intolerância é também combater a homofobia, preferi deixar o termo anti-homofobia no sentido que vai desde a defesa de não-homofóbico ao combate à homofobia.

${ }_{17} \mathrm{Na}$ análise anterior (NASCIMENTO, 2018), ressaltei mais a questão do ethos democrático, mencionando a tolerância como um de seus traços. No entanto, julgo mais pertinente falar de ethos de tolerância, uma vez que ele aparece de modo recorrente.
} 


\section{Gráfico 1}

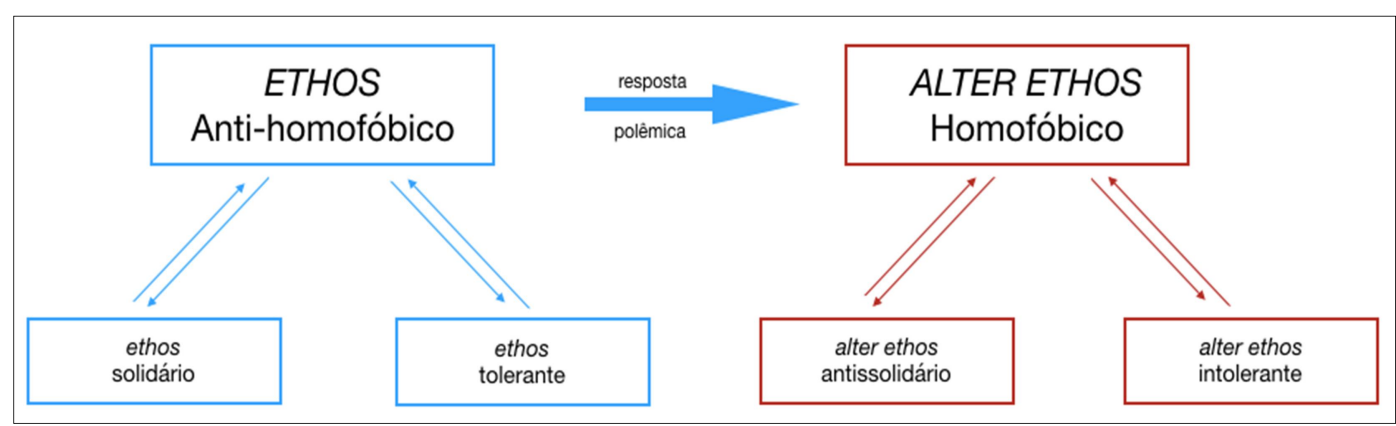

Fonte: Nascimento (2018)

Nessa interação polêmica, a tentativa de correção da imagem de si parece não funcionar muito bem enquanto efeito de sentido, porque a polêmica se instala no sentido do que seria um ethos homofóbico, uma vez que o sentido de homofobia ${ }^{18}$ para os afetivossexuais reformistas é divergente do sentido que os religiosos tradicionalistas apreendem (NASCIMENTO, 2018). Além disso, na polêmica, como a polarização gera certo constraste na construção das identidades dos sujeitos, a correção da imagem torna-se difícil. Isso porque se o outro é homofóbico, eu sou anti-homofóbico; se o outro é antissolidário e intolerante, eu sou solidário e tolerante. Assim, a tentativa de correção da imagem de si fica à mercê da polêmica, porque a desconstrução da imagem em que o outro enquadrou o eu é condição da identidade dele, de maneira que aceitar a desconstrução dessa imagem é desconstruir a sua própria imagem pública.

\section{Considerações finais}

A importância da análise do alter ethos através da forma como o sujeito argumentante constrói seu ethos possibilita compreender melhor como a voz do outro determina a construção argumentativa do eu argumentante. Mas, além disso, é possível observar que o alter ethos gera consequências sobre a ação efetiva. No caso da audiência pública que acabo de analisar, como era

\footnotetext{
${ }^{18}$ Proposto, ainda na década de 1960, pelo psicólogo clínico, norte-americano, George Weinberg, o termo "homofobia" é formado por um processo de junção de dois radicais gregos, homos (semelhante) e phóbos (medo). Weinberg define-o como "o receio de estar com um homossexual em um espaço fechado e, relativamente aos próprios homossexuais, o ódio por si mesmo" (1972, p. 8 apud BORRILLO, 2010, p. 21). Nos debates em torno do PLC 122, os sentidos para esse vocábulo são divergentes: "um grupo se abre à perspectiva discursiva patologizante (discurso tradicional), compreendendo a homofobia como aversão fóbica, violenta e individual ao homossexual; o outro grupo, numa perspectiva afetivossexual militante, compreende o termo como toda uma estrutura social, afetiva e cognitiva que engendra o preconceito e a opressão ao homossexual ou aos sujeitos LGBTs" (NASCIMENTO, 2018, p. 495).
} 
para tratar de colocar ou não o PLC 122 em votação, podemos ver que o alter ethos é determinante, pois o Senador Magno Malta reage à imagem que fazem dele e de seus representados, chegando a se colocar totalmente contra o PLC 122. A razão para isso? Ele se vê atacado, considerado como homofóbico, e enxerga a versão do projeto como uma forma de possibilitar a intolerância aos religiosos cristãos. Ora, se o ethos, como defende Michel Meyer (2007), é o ponto final do questionamento, responsável por reduzir distâncias entre os sujeitos, nesse caso polêmico analisado, ao contrário, ele é um dos responsáveis pelo distanciamento.

Veja que, ao mobilizarmos essa noção de alter ethos, a polemicidade e os valores amados e odiados podem ser vistos sob a perspectiva de como os sujeitos se constroem frente ao olhar hostil do outro ${ }^{19}$. Esse olhar sobre o ethos amplia as possibilidades de compreensão das relações argumentativas, uma vez que vai à gênese da relação intersubjetiva, a qual diz respeito ao movimento empático do self com seu outro, ou como diz Bakhtin (2010, 2011), o eu para mim, o outro para mim e o eu para o outro.

Ademais, como observamos, essa noção permite-nos ver como o outro reage à desqualificação operada por seu adversário. Com isso, sob um ângulo privilegiado, podemos ver a dialogicidade da linguagem atuando na constituição da intersubjetividade dos atos humanos.

\section{Referências}

ANGENOT, Marc. Dialogues de sourds: traité de rhétorique antilogique. Paris: Mille et une nuits/Fayard, 2008.

AMOSSY, Ruth. Da noção retórica de ethos à análise do discurso. In: Imagens de si no discurso: a construção do ethos. Tradução: Dilson F. Cruz et al. São Paulo: Contexto, 2008.

. L'argumentation dans le discours. Paris: Armand Colin, 2010.

. Apologie de la polémique. Paris: Presses Universitaires de France, 2014.

ARISTÓTELES. Retórica. Tradução: Marcelo Silvano Madeira. São Paulo: Riddel, 2007.

BAKHTIN, Mikhail. Para uma filosofia do ato responsável. Tradução: Valdemir Miotello e Carlos Alberto Faraco. São Carlos: Pedro \& João editores, 2010.

Fontes, 2011.

. Estética da criação verbal. Tradução: Paulo Bezerra. São Paulo: Martins

\footnotetext{
${ }^{19}$ Não apenas nesta análise, mas obtive essa constatação com análises de outros alter ethos em minha tese de doutorado, quais sejam: o alter ethos de incapacidade, do alter ethos totalitário e do alter ethos do dissenso (NASCIMENTO, 2018).
} 


\section{$\mathrm{EI} \square \mathrm{dA}$}

Revista Eletrônica de Estudos Integrados em Discurso e Argumentação, Ihéus, n. 18, abr.2019.

- Problemas da poética de Dostoiévski. Tradução: Paulo Bezerra. Rio de

Janeiro: Forense Universitária, 2013.

BORRILLO, Daniel. Homofobia: história e crítica de um preconceito. Tradução: Guilherme João de Freitas Teixeira. Belo Horizonte: Autêntica, 2010.

BRASIL. SENADO FEDERAL DO BRASIL. COMISSÃO DE DIREITOS HUMANOS (CDH). Audiência Pública: Ata da $96^{\mathrm{a}}$ reunião (extraordinária) da comissão permanente de direitos humanos e legislação participativa, da $1^{\mathrm{a}}$ sessão legislativa ordinária da $54^{\mathrm{a}}$ legislatura. Brasília: Senado federal, 2011. Disponível em http://legis.senado.leg.br/sicon/index.html\#/pesquisa/lista/documentos. Acesso em 15 de julho de 2014.

CHARAUDEAU, Patrick. Discurso político. Tradução: Fabiana Komesu e Dilson Ferreira da Cruz. São Paulo: Contexto, 2013.

DUCROT, Oswald. Dizer e o dito. Revisão técnica da tradução: Eduardo Guimarães. Campinas: Pontes, 1987.

LEITÃO, Selma. Apontamentos sobre o diálogo Perelman-Bakhtin. In: LEMGRUBER, Márcio Silveira; OLIVEIRA, Renato José (Org.). Teoria da argumentação e educação. Juiz de Fora: Editora UFJF, 2011. p. 57-70.

MAINGUENEAU, Dominique. Cenas da Enunciação. Tradução: Sírio Possenti. Curitiba: Criar Edições, 2006.

. A propósito do ethos. Tradução: Luciana Salgado. In: MOTTA, Ana Raquel; SALGADO, Luciana. Ethos discursivo. São Paulo: Contexto, 2008.

MEYER, M. A retórica. Tradução: Marly N. Peres. Revisão técnica: Lineide Salvador Mosca. São Paulo: Ática, 2007.

NASCIMENTO, Lucas. Análise dialógica da argumentação: a polêmica entre afetivossexuais reformistas e cristãos tradicionalistas no espaço político. 557f. 2018. Tese (Doutorado em Língua e Cultura), Universidade Federal da Bahia, 2018.

PAVEAU, Marie-Anne. Os pré-discursos: sentido, memória, cognição. Tradução: Graciely Costa e Débora Massmann. Campinas: Pontes Editores, 2013.

PERELMAN, Chaim; OLBRECHTS-TYTECA, Lucie. Tratado da argumentação: a nova retórica. Tradução: Maria Ermantina de Almeida Prado Galvão. 2. ed. São Paulo: Martins Fontes, 2005.

\section{Forma de citação sugerida}

NASCIMENTO, Lucas. Quando o alter ethos é homofóbico. EID\&A - Revista Eletrônica de Estudos Integrados em Discurso e Argumentação, Ilhéus, n. 18, p. 57-73, abr.2019. DOI dx.doi.org/10.17648/eidea-18-2198. 